\title{
Reducing Carbon Emissions through Improved Forest Management in Cambodia
}

\author{
Nophea Sasaki ${ }^{1}$, Issei Abe ${ }^{1}$, Vathana Khun ${ }^{2}$, Somanta Chan $^{1}$, Hiroshi Ninomiya ${ }^{1}$, Kimsun Chheng $^{2}$ \\ ${ }^{1}$ Graduate School of Applied Informatics, University of Hyogo, Kobe, Japan; ${ }^{2}$ Forestry Administration, Phnom Penh, Cambodia. \\ Email: nopsasaki@gmail.com \\ Received October $18^{\text {th }}, 2013$; revised November $12^{\text {th }}, 2013$; accepted November $20^{\text {th }}, 2013$ \\ Copyright (C) 2013 Nophea Sasaki et al. This is an open access article distributed under the Creative Commons Attribution License, \\ which permits unrestricted use, distribution, and reproduction in any medium, provided the original work is properly cited.
}

\begin{abstract}
Carbon emissions from selectively logged forests in the tropics are strongly affected by logging practices. Although tropical forests are mainly managed under the concession system, only a handful of studies were done to assess the impact of logging practices on emission reductions and future timber supply. In this report, carbon stocks, timber supply, and carbon emission reductions under conventional logging (CVL), reduced-impact logging (RIL), and RIL with special silvicultural treatments (RIL+) were assessed in 3.4 million ha of concession forests for a 55-year project time span. Carbon emissions under a 25-year CVL practiced in Cambodia were estimated at $12.4 \mathrm{TgCO}_{2}$ year ${ }^{-1}$ for 55 years. We then tested four cutting cycles of selective logging and our results suggest that a 45-year selective cutting cycle was appropriate for managing concession forests in Cambodia in terms of maintaining commercial timber supply and reducing carbon emissions. By considering RIL or RIL+ as a new logging practice for improving forest management in the tropics, carbon credits from selective logging in Cambodia were estimated at $6.2-7.9 \mathrm{TgCO}_{2}$ or about $\$ 31.0-39.5$ million annually if carbon is priced at $\$ 5$. It is concluded that RIL or RIL+ should be adopted for "sustainable management of forests" element of the REDD+ scheme.
\end{abstract}

Keywords: Carbon Credits; Forest Inventory; Liberation Treatment; Reduced Impact Logging; Timber Concession; Wood Supply

\section{Introduction}

The anticipated REDD+ (reducing emissions from deforestation and forest degradation, forest conservation, sustainable forest management, and enhancement of carbon sinks) agreements have attracted increasing research to estimate the carbon emission reductions and the associated costs of implementing the specified management activities, and how such emission reductions can be monitored and verified. Recent data suggest that between 2000 and 2009, land use change (mostly tropical deforestation) was responsible for the release of $1.1-2.7 \mathrm{PgC}$ (about 4 billion tonnes $\mathrm{CO}_{2}$ ) [1,2]. Kindermann et al. [3] suggest that $50 \%$ of carbon emissions from tropical deforestation could be halted at carbon prices of $\$ 5.20$ 38.15 per $\mathrm{MgCO}_{2}$ (tonne $\mathrm{CO}_{2}$ ) varying by continents. Sasaki and Yoshimoto [4] focused on the opportunity costs of managing tropical forests versus clearing these forests to develop industrial plantations, and suggested that managing tropical forests for timber production under the REDD + mechanism would be preferable because of the huge potential revenues and other benefits from the ecosystem services provided by these forests. Toni [5] suggests the need for REDD+ decentralization in order to effectively manage the revenues from REDD + scheme while protecting tropical forests. Although previous studies clarified the fundamental basis for understanding the potential of REDD+, achieving carbon emission reductions and maintaining timber supply from the selectively logged forests are still debatable [6,7].

Furthermore, sustained global efforts to mitigating climate change through the REDD+ scheme were evident at the $17^{\text {th }}$ and $18^{\text {th }}$ Conference of the Parties (COP17 and COP18) of the United Nations Framework Convention on Climate Change (UNFCCC) held in Durban, South Africa and Doha, Qatar in 2011 and 2012 as good progress on setting up reference emission levels (REL), defining the measurements of emission reductions from forestry initiatives, and safeguarding the social and environmental benefits was achieved. Despite such achievements, estimation of carbon emissions and reduced emis- 
sions, especially in the "sustainable management of forests or SFM" element of REDD+ scheme remained to be addressed.

SFM is an important component because it helps stabilize the timber market, maintains wood supply from tropical forests to meet increasing demands for wood while generating employment and revenues for owners of the forest resource or for governments in developing countries. SFM is strongly affected by logging practices [8-11], and logging practices for commercial timber production are usually carried out in production forests under the forest concession system. As logging practices resulted in various degrees of logging damages and wood wastes, they strongly affect the end-use wood supply and carbon stocks in the forests [12-14]. Therefore, it is important to determine the appropriate logging practice that is sustainable and economical in terms of continuous flow of wood products and other forest ecosystem services. Such practice is obviously important for achieving the SFM element of the REDD+ scheme.

To better inform the policy makers as well as climate change negotiators, there is a critical need for developing methods for estimating the carbon emissions with and without the REDD+ activities as well as emission reductions resulted from the implementation of SFM. Until recently, only a handful of studies were carried at regional [12] and global [6,7] to estimate timber supply and carbon retention in selectively logged forests where logging practices affect both timber supply and carbon stocks. In this paper, we aim to estimate the potentials of carbon emission reductions from managing concession forests in Cambodia using available models.

\section{Study Methods and Materials}

\subsection{Cambodia and REDD+}

Cambodia and REDD+: Cambodia ratified the UNFCCC in 1995 and acceded to its Kyoto Protocol in 2002. In addition to contributing to emission reduction efforts in energy sector, Cambodian government has put strong commitment on managing forests under the REDD+ scheme [15]. A REDD+ pilot project in Oddar Meanchey province was awarded Dual Gold Validation by the Climate, Community \& Biodiversity Standard and the Verified Carbon Standard. Project Design Document for another REDD+ project in Seima Protected Forests, Mondulkiri province was submitted to a carbon standard for validation. In 2011, the Japanese Ministry of Environment and Ministry of Economy, Trade and Industry provided subsidies, respectively to Conservation International and Japan Forest Technical Association for two feasibility study projects on REDD+ in Prey Long (Kampong Thom province) and Phnom Tbeng Protected Forests (Preah Vihear province), Cambodia. The Forestry and Forest Products Research Institute (Japan) in collaboration with Cambodia's Forestry Administration has conducted research on developing Monitoring, Reporting and Verification (MRV) system for REDD+ projects in Cambodia since 2010. All these projects showed increasing interests in REDD+ projects in Cambodia. Nevertheless, these projects focused only on protected and community forests although concession forests still account for 30\% of the total forest cover in Cambodia. This study is the first attempt to introduce project ideas for managing the production forests under the REDD+ scheme's SFM element.

Forests and concession forests in Cambodia: FAO [16] categorized the world's forests according to their functions. They are forests for production $(30 \%$ of the global forests), protection of soil and water $(8 \%)$, conservation of biodiversity $(12 \%)$, social services $(4 \%)$, multiple use (24\%), other (7\%), and unknown (16\%) functions. Production forests are where logging for commercial timber production is allowed. Production forests in the tropics are commonly managed under forest concession system, a system that government as forest resource owner issues logging license to logging companies i.e. forest concessionaire to harvest the timber as per guidelines and laws of the countries in concerns. In 2010, Cambodia has a total forest cover of 10.4 million ha or about $57.1 \%$ of the country's total land area [17]. Deforestation rate was estimated at about $0.7 \%$ between 1973 and 2003 [13], and about $0.8 \%$ between 2002 and 2010 [17]. There are three major forest types in Cambodia namely evergreen, semi-evergreen, and deciduous forests. Other forest types include inundated and mangrove forests, and forest plantations but they represent only a small proportion of the total forest cover. Evergreen, semi-evergreen, and deciduous forests annually lost about $0.7 \%, 1.5 \%$, and $0.9 \%$, respectively between 2002 and 2010 [17]. Based on their functions, the 10.4 million of forests are classified to concession $(32.7 \%)$, protection $(43.3 \%)$, and conversion forests $(24.0 \%)$, respectively (Figure 1). The 3.4 million ha of concession forests are under the jurisdiction of Forestry Administration of the Ministry of Agriculture, Forestry, and Fisheries (MAFF). Protection forests include 1.4 million ha of forests under the jurisdiction of the FA and 3.1 million ha of protected areas under the jurisdiction of the Ministry of Environment, and mangrove and inundated forests under the jurisdiction of Fisheries Administration. Conversion forests are under jurisdiction of MAFF. Large-scale logging by forest concessionaires was suspended in late 2001 due to concern over indiscriminate logging and rapid forest degradation. Despite logging ban, small-scale logging is still going on to harvest timber to supply the domestic demands in Cambodia. A permanent logging ban would not solve the problems of forest protection and wood 


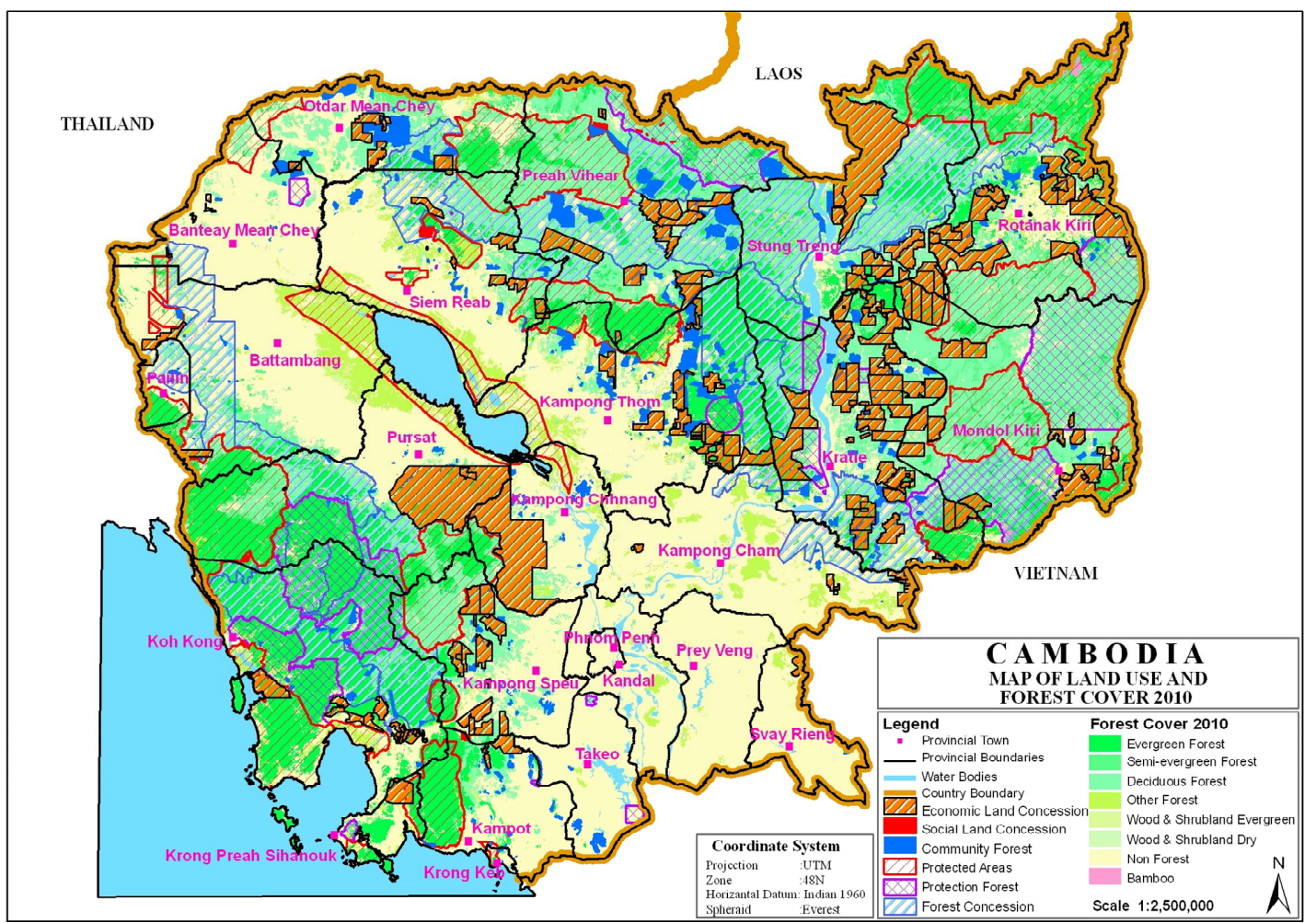

Figure 1. Location map of forest land uses (including forest concessions) in Cambodia in 2008. Source: Courtesy of Cambodia's Forestry Administration.

shortage for growing population and economic developments because if wood demand is increasing, it is likely that timber price will also be increasing. At a point in time when timber price is high enough comparable to carbon-based revenues from protecting, logging (either legal or illegal) can no longer be controlled. Therefore, the most appropriate alternative is to continue logging but under a sound management system that can ensure longterm sustainability of wood supply while reducing carbon emissions from unsustainable management practices. As concessions in Cambodia were granted under a long-term contract, we assume the area of forest concessions (3.4 million ha) in Cambodia remains unchanged during the timeframe for this study (corresponding to 55-year project time span). Prior to logging ban, a 25 -year selective cutting cycle was used for managing concession forests in Cambodia. We therefore use 25-year cutting cycle as our business-as-usual or baseline cutting cycle.

Major commercial tree species being harvested in Cambodia include Chorchong (in local name) (Shorea vulgaris of Dipterocarpaceae), Lumboi (Shorea sp., Dipter ocarpaceae), Phdeak (Anisoptera glabra, Dipterocarpaceae), Chheutieal (Dipterocarpus costatus, Dipterocarpaceae), Krakos (Sindora conchinchinnensis, Caesalpinaceae), and Dauchem (Tarrietia javanica, Sterculiaceae). DHB (diameter at breast height) for all these trees must be greater the diameter limit for harvest.

\subsection{Logging Scenarios: CVL, RIL, RIL+}

Most logging practices in tropical are carried out with little or without proper management plan and untrained staff $[7,18]$. Such logging is termed here as conventional logging (CVL). CVL scenario refers to logging practices that require neither formal planning nor the use of trained staff. CVL causes large amounts of damage to the residual stand and wastes large amounts of wood both in the forest and at sawmill or pulp and paper plant [19]. In contrast, RIL and RIL+ scenarios are referred to logging scenario using reduced-impact logging (RIL) and RIL+ (plus), which includes RIL and a "liberation" treatment. RIL is a logging practice that involves proper training of the logging staff; well-defined logging plans; careful planning of main, secondary, and feeder road locations before harvesting and extraction; the use of directional felling; cutting stumps low to the ground; minimizing wood waste caused by felling, skidding, and road transportation; minimizing road and trail widths; minimizing landing size and maximizing landing spacing; minimizing ground disturbance; paying attention to forest aesthetics; and minimizing damage to the residual stand. Sasaki and Putz [10] and Holmes et al. [19] provide more details about RIL practices. RIL is a promising logging practice for managing tropical forests [7,11], because it involves careful planning to minimize waste and adverse 
impacts on the residual stand. RIL+ is exactly the same as RIL, except that it additionally adopts a liberation silvicultural treatment, in which unwanted defective trees that are competing with future crop trees are girdled to kill them. By so doing, forest growth can be accelerated. Recent studies suggests that by reducing the competition from unwanted trees, growth rates of the crop trees can be increased by $20 \%$ to $60 \%$ compared with the growth rate in forests where only RIL is implemented [20,21]. For this study, a $50 \%$ increase rate was assumed for RIL+.

\subsection{Logging Impact on Carbon Stocks}

Using same approach of Sasaki et al. [6], aboveground carbon stocks in concession forests in Cambodia under the CVL, RIL, and RIL+ scenarios can be derived by:

$$
\begin{gathered}
\frac{\mathrm{dCS}_{\mathrm{i}}(\mathrm{t})}{\mathrm{dt}}=\operatorname{MAI}-\left[\mathrm{LM}_{\mathrm{i}}(\mathrm{t})-\mathrm{H}_{\mathrm{i}}(\mathrm{t})\right] \times \mathrm{BEF} \\
\mathrm{H}_{\mathrm{i}}(\mathrm{t})=\frac{\mathrm{f}_{\mathrm{M}} \times \mathrm{f}_{\mathrm{H}}}{1-\mathrm{r}} \times \frac{\mathrm{CS}_{\mathrm{i}}(\mathrm{t})}{\mathrm{T}_{\mathrm{c}} \times \mathrm{BEF}} \\
\mathrm{LM}_{\mathrm{i}}(\mathrm{t})=\alpha_{i} \times \mathrm{H}_{\mathrm{i}}(\mathrm{t})
\end{gathered}
$$

where:

$\mathrm{CS}_{\mathrm{i}}(\mathrm{t})$ : aboveground carbon stock $\left(\mathrm{MgC} \mathrm{ha} \mathrm{h}^{-1}\right)$ under logging system i ( $\mathrm{i}$ is CVL, RIL, or RIL+) in year t. Forest management was assumed to start in 2014 and simulation is run for 55 years from 2014.

MAI: mean annual increment $\left(\mathrm{MgC} \mathrm{ha}{ }^{-1}\right.$ year $\left.^{-1}\right)$.

$\mathrm{LM}_{\mathrm{i}}(\mathrm{t})$ : carbon in dead trees lost due to logging damages $\left(\mathrm{Mg} \mathrm{C} \mathrm{ha}^{-1} \cdot\right.$ year $\left.^{-1}\right)$.

$\alpha_{\mathrm{i}}$ : Rate of logging damages to residual stands in proportional to $\mathrm{H}_{\mathrm{i}}(\mathrm{t})$.

$\mathrm{H}_{\mathrm{i}}(\mathrm{t})$ : harvested carbon $\left(\mathrm{Mg} \mathrm{C}^{-1} \cdot \mathrm{year}^{-1}\right)$.

$\mathrm{BEF}$ : biomass expansion factor. $\mathrm{BEF}=1.74$ [22].

$\mathrm{f}_{\mathrm{M}}$ : proportion of mature trees. Defined as trees having DBH $\geq$ DBH limit for harvesting in Cambodia. Proportion of standing volume of mature trees to total stand volume was estimated at $52.7 \%-56.3 \%$ with a mean of $54.1 \%$ in Kampong Thom, Cambodia [23]. For this study, $54 \%\left(f_{M}=0.54\right)$ was assumed.

$\mathrm{f}_{\mathrm{H}}$ : legal rate of harvesting permitted by the government. Sub-decree 050 of the MAFF specifies that only $30 \%-50 \%$ of the mature trees can be harvested depending on how dense the forest is [24]. For this study, 30\% of the mature trees $\left(f_{H}=0.3\right)$ was assumed because Cambodia's forests have been logged to various degrees since late 1980s.

r: rate of illegal logging. During 1997 and 1998, rate of illegal logging was estimated at about $67 \%$ of the total harvested wood [25]. This rate is comparable to rates in other countries in the tropics such as $50 \%-88 \%$ in Indonesia [26,27], up to $70 \%$ in Ghana [28], 50\% in Cam- eroon and up to $50 \%-75 \%$ in the Brazilian Amazon [29]. As Cambodia became a peaceful country and the entire country is governed by one government, it is likely that rate of illegal logging has decreased since 1998. For this study, $50 \%$ rate $(r=0.5)$ was therefore assumed. As illegal logging is very sensitive political issue in Cambodia, this assumption should be revised when data become available.

$\mathrm{T}_{\mathrm{c}}$ : cutting cycle (years). Cambodia adopted a 25 -year cutting cycle, and this cycle is used here as a baseline cycle. To determine an appropriate logging cycle for managing concession forests in Cambodia, three more cutting cycles, namely 35-year, 45-year, and 55-year were tested.

Initial value for $\mathrm{CS}(\mathrm{t})$ in Equation (1) is $92.7 \mathrm{MgC} \mathrm{ha}^{-1}$ based on the weighted average of forest area by type (evergreen, semi-evergreen and deciduous forests) in 2010 and stand volumes published in Kim Phat et al. [23,30,31], Kao and Iida [32], and Chheng et al. [33]. Little study on Mean Annual Increment (MAI) has been done in Cambodia. Top et al. [34] estimated the increment of aboveground biomass of mostly small trees in 32 sample plots at $4.77 \mathrm{Mg} \mathrm{ha}^{-1} \cdot$ year $^{-1}(4.77 \times 0.5$ carbon content in dry wood $=2.4 \mathrm{MgC} \mathrm{ha}^{-1}$ ) between 1998 and 2000 in Kampong Them province, Cambodia. Long-term studies from permanent sample plots suggested that MAIs in tropical Amazon forests range from $0.64 \mathrm{tC}$ $\mathrm{ha}^{-1} \cdot$ year $^{-1}$ [35] to $0.72 \mathrm{MgC}$ [36]. Previous study in Cambodia put the MAI of the natural undisturbed forests at $0.33 \mathrm{~m}^{3} \mathrm{ha}^{-1} \cdot \mathrm{year}^{-1}$ or about $0.2 \mathrm{MgC}$ of aboveground carbon [37]. In Indonesia, MAI in commercially logged forests was $1.13 \mathrm{~m}^{3} \mathrm{ha}^{-1} \cdot$ year $^{-1}$ or about $0.56 \mathrm{MgC}$ of aboveground carbon [38]. Due to the lack of data on MAIs in natural forests in neighboring countries for comparison, it is assumed that the MAI in production forests in Cambodia is $1 \mathrm{~m}^{3} \cdot \mathrm{ha}^{-1} \cdot$ year $^{-1}$ or $0.5 \mathrm{MgC}$ (MAI $=0.5$ ) under CVL and RIL, and $0.75 \mathrm{MgC}$ under RIL+ (50\% increase in growth rate).

A recent study on logging damages to stand volume under a RIL experiment in Cambodia found that $18 \%$ $20 \%$ of the stand volume were damaged, of which about $8.3 \%\left(12.0 \mathrm{~m}^{3} \mathrm{ha}^{-1}\right.$ or $\left.5.9 \mathrm{MgC} \mathrm{ha}^{-1}\right)$ died immediately after logging [33]. No study on logging damages under CVL was available in Cambodia. A collection of logging damages in Brazil, Malaysia, and Indonesia [10] suggested that logging damages under RIL were about $30 \%$ lower than that under the CVL. Therefore, the $8.3 \%$ under the RIL reported by Chheng et al. [33] above is equivalent to $27.7 \%$ [27.7 $=8.3 / 0.3]$ under the $\mathrm{CVL}$ or $40.0 \mathrm{~m}^{3} \mathrm{ha}^{-1}$ per a 25 -year cycle or about $1.6 \mathrm{~m}^{3} \mathrm{ha}^{-1}$ year $^{-1}$ (based on data of stand volume in [33]. Including $50 \%$ illegal logging rate gave the total harvested at 3.2 $\mathrm{m}^{3}$ ha $^{-1}$ year $^{-1}(3.2=1.6 / 0.5)$.

Because logging damages under both CVL and RIL were strongly affected by harvesting density [39], dam- 
ages to stand volume here were set to equate to the harvesting density $(\alpha=1)$ with the initial value of $1 \mathrm{MgC}$ or $3.7 \mathrm{~m}^{3} \cdot \mathrm{ha}^{-1} \cdot$ year $^{-1}[3.7=1 /(0.57 \times 0.5)]$, which is comparable to that derived from Chheng et al. [33] under the CVL and 50\% reduction $(\alpha=0.5)$ under RIL and RIL+. Aboveground carbon was derived using approach developed by Brown [22], which aboveground carbon is the product of stand volume, wood density (0.57), BEF (1.74) and carbon content in dry wood (0.5).

Parameters and initial values for Equations (1) and (2) are provided in Table $\mathbf{1}$.

\subsection{Wood Products Model}

Managing concession forests is important for commercial timber supply and improving forest ecosystems. Under CVL, RIL, and RIL+, we calculated the quantities of the following wood components: wood products (WP), wood waste (WAS), logging mortality (LM), end-use wood products (EWP), and end-use wood waste at sawmill or pulp and paper mill (EWAS). To do so, we used the following equations from Sasaki et al. [6]:

$$
\begin{aligned}
\operatorname{WP}_{\mathrm{i}}(\mathrm{t}) & =(1-\mathrm{s})_{\mathrm{i}} \times \mathrm{H}_{\mathrm{i}}(\mathrm{t}) \\
\mathrm{WAS}_{\mathrm{i}}(\mathrm{t}) & =\mathrm{H}_{\mathrm{i}}(\mathrm{t})-\mathrm{WP}_{\mathrm{i}}(\mathrm{t}) \\
\operatorname{EWP}_{\mathrm{i}}(\mathrm{t}) & =\left(1-\mathrm{a}_{\mathrm{i}}\right) \times \mathrm{WP}_{\mathrm{i}}(\mathrm{t}) \\
\operatorname{EWAS}_{\mathrm{i}}(\mathrm{t}) & =\mathrm{WP}_{\mathrm{i}}(\mathrm{t})-\operatorname{EWP}_{\mathrm{i}}(\mathrm{t})
\end{aligned}
$$

where:

$\mathrm{s}_{\mathrm{i}}$ : proportion of unusable wood such as broken merchantable stem and high stump caused by unprofessional tree felling, log skidding and/or transporting under logging practice i (CVL, RIL, or RIL+).

No study on this proportion was conducted in Cambodia. The proportion of unusable wood was estimated at $24.7 \%, 20.0 \%, 46.2 \%$, and $24.0 \%$ under CVL but was reduced $14.5 \%, 0 \%$, to $26.2 \%$, and $8 \%$ under RIL, respectively in East Kalimantan, Indonesia [14], Sarawak, Malaysia [41], East Kalimantan [42], and Eastern Amazon [19]. For this study, it is assumed at $30 \%$ and $10 \%$ under CVL and RIL (the latter includes RIL and RIL+), respectively.

$\mathrm{a}_{\mathrm{i}}$ : wood processing inefficiency (lost wood due to processing) under system i. Wood processing efficiency in Cambodia under CVL was reported at 35\% - 51\% [40]. For this study, inefficient rate was assumed that $50 \%$ under CVL and 40\% under RIL (including RIL+).

The units of WP, WAS, LM, EWP, and EWAS are $\mathrm{MgC} \mathrm{ha}{ }^{-1} \cdot$ year $^{-1}$, otherwise stated.

\subsection{Wood Harvesting and Supply}

Regardless how much timber is harvested in the forests, final wood products (i.e. EWP) ready to be used for furniture and/or other infrastructure construction are important. Therefore such wood products need to be maintained through the adoption of appropriate logging practices. To compare harvesting density in each logging practice, it was assumed that the EWP produced under the CVL system is a timber supply baseline against which the EWPs from RIL and RIL+ are compared. Maintaining same final wood products under the three logging practiced is expressed by:

Table 1. Summarizes the values of these parameters, the underlying assumptions, and the sources of these data.

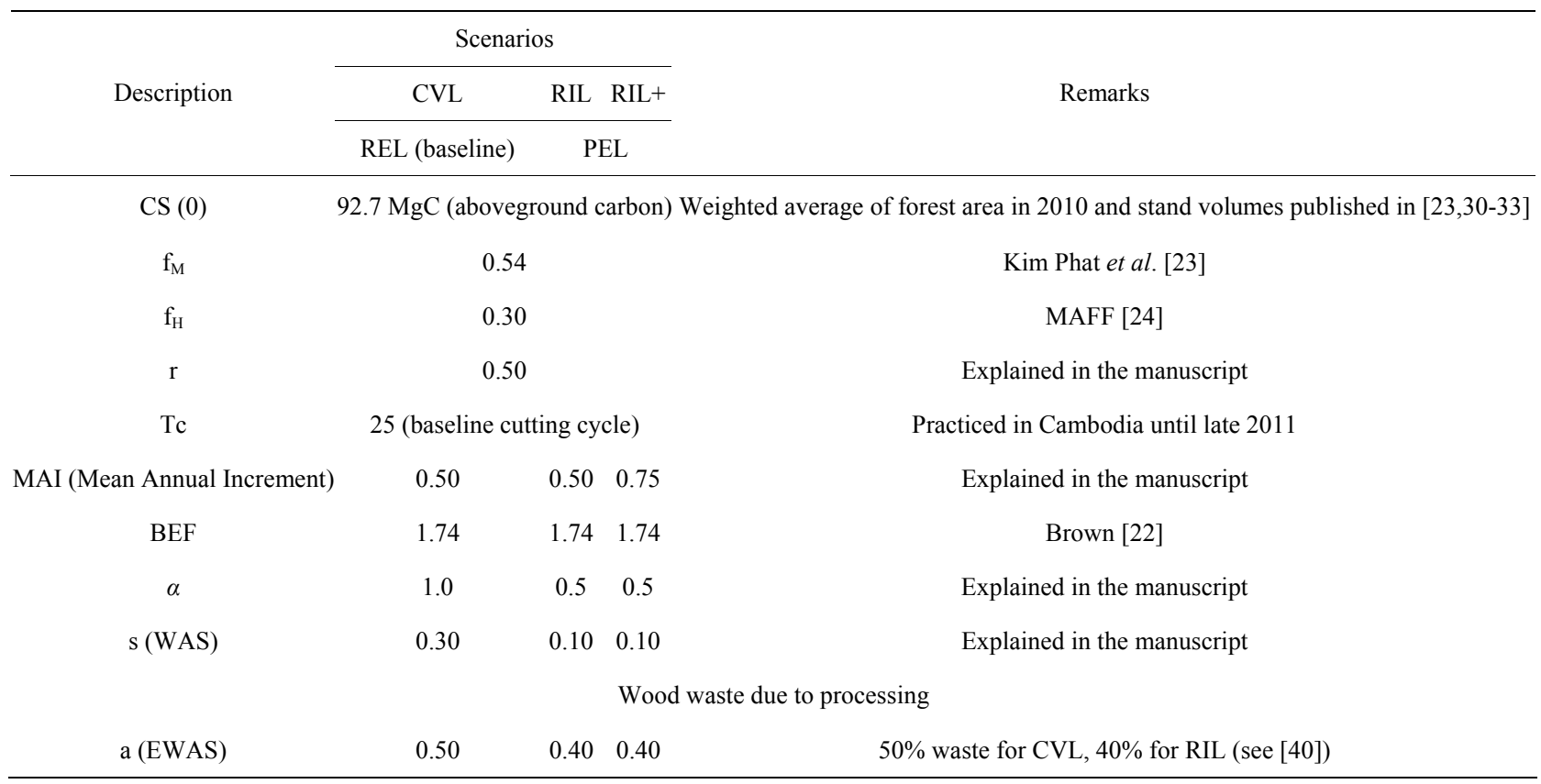




$$
\begin{gathered}
\operatorname{EWP}_{\mathrm{CVL}}(\mathrm{t})=\left(1-\mathrm{a}_{\mathrm{CVL}}\right) \times \mathrm{WP}_{\mathrm{CVL}}(\mathrm{t}) \\
\operatorname{EWP}_{\mathrm{R}}(\mathrm{t})=\left(1-\mathrm{a}_{\mathrm{R}}\right) \times \mathrm{WP}_{\mathrm{R}}(\mathrm{t})
\end{gathered}
$$

where the subscript " $\mathrm{R}$ " means that the equation can be used for both RIL and RIL+.

To maintain a long-term wood supply under the REDD+ scenario (using RIL or RIL+) that is comparable to that under the baseline scenario (using CVL), the wood supply under the three scenarios must be maintained:

$$
\operatorname{EWP}_{\mathrm{R}}(\mathrm{t})=\operatorname{EWP}_{\mathrm{CVL}}(\mathrm{t})
$$

or

$$
H_{R}(t)=\frac{\left(1-a_{C V L}\right)\left(1-s_{C V L}\right)}{\left(1-a_{R}\right)\left(1-s_{R}\right)} \times H_{C V L}(t)
$$

\subsection{Emission Reductions and Carbon Credits}

Accounting for carbon stocks and emission reduction is an important component of the Monitoring, Reporting, and Verification or MRV system of the REDD+ scheme and for setting reference emission level. Unlike REDD projects where carbon stocks and emissions can be simply obtained by multiplying annual deforested area and carbon stocks per hectare, area of concession forests usually does not change. Only carbon stocks change because of logging impact. To estimate carbon credits from managing concession forests, baseline emissions and project emissions should be accounted for. The former is the emission in the absence of international agreements that provide incentives for good longterm logging practices (CVL in this study) while the latter is the emission released from project implementation (RIL and RIL + in this study). In addition to baseline emissions (BE) and project emissions (PE), leakages (L) are the emissions outside the project boundaries, which need to be taken into account as well. Carbon credits (CC) from managing concession forests can be derived by:

$$
\begin{gathered}
\mathrm{CC}(\mathrm{t})=[\mathrm{BE}(\mathrm{t})-\mathrm{PE}(\mathrm{t})-(1-\mathrm{L}(\mathrm{t}))] \times 3.4 \\
\mathrm{BE}(\mathrm{t})=\left[\mathrm{CS}_{\mathrm{CVL}}(\mathrm{t}+1)-\mathrm{CS}_{\mathrm{CVL}}(\mathrm{t})\right] \times \frac{44}{12} \\
\mathrm{PE}(\mathrm{t})=\left[\mathrm{CS}_{\mathrm{RIL}}(\mathrm{t}+1)-\mathrm{CS}_{\mathrm{RIL}}(\mathrm{t})\right] \times \frac{44}{12} \\
\operatorname{PEL}(\mathrm{t})=\left[\mathrm{CS}_{\mathrm{RIL}+}(\mathrm{t}+1)-\mathrm{CS}_{\mathrm{RIL}+}(\mathrm{t})\right] \times \frac{44}{12}
\end{gathered}
$$

where:

$\mathrm{BE}(\mathrm{t})$ : Baseline emission at year $\mathrm{t}\left(\mathrm{MgCO}_{2}\right.$ year $\left.^{-1}\right)$. CVL emissions are taken as baseline emissions.

$\mathrm{PE}(\mathrm{t})$ : Project emission at year $\mathrm{t}\left(\mathrm{MgCO}_{2}\right.$ year $\left.^{-1}\right)$.

$\mathrm{L}(\mathrm{t})$ : Leakages $\left(\mathrm{MgCO}_{2}\right.$ year $\left.^{-1}\right)$. Murray et al. [43] found that leakages vary greatly from one location to another. It was at $30 \%$ for our study.

$\mathrm{CS}_{\mathrm{CVL}}(\mathrm{t}), \mathrm{CS}_{\mathrm{RIL}}(\mathrm{t}), \mathrm{CS}_{\mathrm{RIL}+}(\mathrm{t})$ : Carbon stocks in the year $\mathrm{t}$ under CVL, RIL, and RIL+ scenarios, respectively $(\mathrm{MgC})$.

3.4 (3.4 million ha): total area of concession forests in Cambodia.

44/12: the ratio of the molecular weight of $\mathrm{CO}_{2}$ (44) to the molecular weight of carbon (12).

\subsection{End-Wood Products and Overall Carbon Stocks}

Total end-use wood products and carbon stocks for each scenario from managing 3.4 million ha of concession forests in Cambodia are the products of respective variables with area of concession forests. Converting EWP from carbon $(\mathrm{TgC})$ to cubic meter $\left(\mathrm{m}^{3}\right)$ was done following Brown [22].

$$
\operatorname{EWP}_{\mathrm{m} 3}(\mathrm{t})=\frac{\operatorname{EWP}(\mathrm{t})}{\mathrm{WD} \times \mathrm{BEF} \times \mathrm{C}}
$$

where:

$\mathrm{EWP}_{\mathrm{m} 3}(\mathrm{t})$ : total end-use wood products in million $\mathrm{m}^{3} \cdot$ year $\left.^{-1}\right)$.

EWP $(t)$ : total end-use wood products in $\mathrm{TgC}$ year $^{-1}$.

WD: wood density in dry biomass $(\mathrm{WD}=0.57)$.

$\mathrm{C}$ : carbon content in dry wood $(\mathrm{C}=0.5)$.

\section{Results and Discussions}

Modeling timeframe for this study is 55 years commencing in 2014.

\subsection{End-Use Wood Products and Wood Wastes under CVL, RIL and RIL+}

By maintaining end-use wood products under both CVL and RIL (including RIL+), annual end-use wood products and wood wastes were estimated under the current cutting cycle of 25 years. Our models suggested that managing 3.4 million ha of concession forests over 55 years in Cambodia produces, about 1.8 million $\mathrm{m}^{3} \cdot \mathrm{year}^{-1}$ of the end-use wood product at a declining rate of $1.1 \%$ annually from 2.9 million $\mathrm{m}^{3}$ in 2010 (Figure 2). In terms of logging residues (in forests) and wood wastes (at the sawmill), CVL created 3.4 million $\mathrm{m}^{3} \cdot \mathrm{year}^{-1}$ over the same period while only 1.6 million $\mathrm{m}^{3} \cdot$ year $^{-1}$ of wastes were created under the RIL (including RIL and RIL+), reducing $52.9 \%$ of residues and wastes due to logging. Logging residues and wood wastes under CVL resulted from huge damages and wood wastes caused by unprofessional logging, log skidding, trimming and transporting, and wastes at sawmill. Switching from CVL to RIL or RIL+ practice could significantly reduce wood wastes, and therefore vulnerability of forests to fires [44].

Illegal logging strongly influences the end-use wood products and carbon stocks in the forests. If $50 \%$ of the 


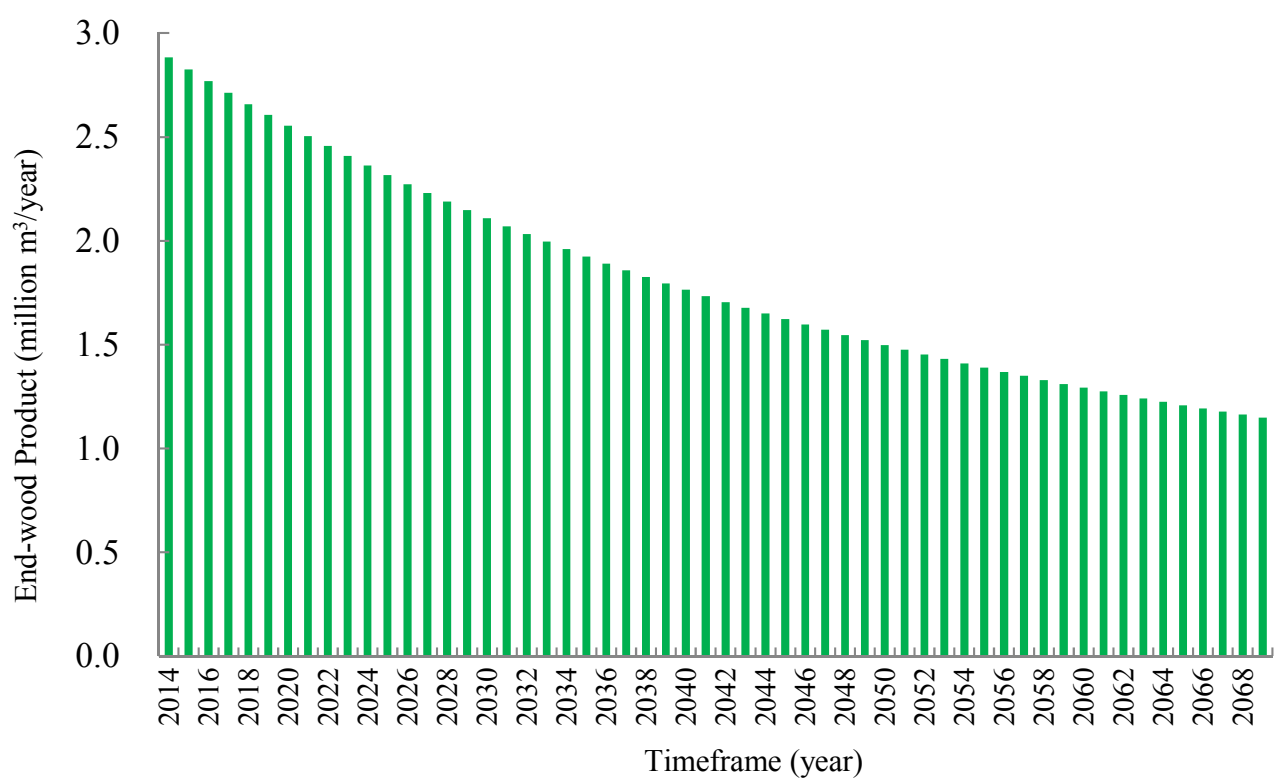

Figure 2. Annual end-use wood products ensured under three logging practices for 55 years (2010-2065).

illegal logging rate is eliminated $(r=0.5 / 2)$, wood supply is maintained at 1.4 million $\mathrm{m}^{3}$.year ${ }^{-1}$ but declining rate is at about $0.6 \%$. If illegal logging is completely eliminated $(\mathrm{r}=0)$, wood supply is maintained at 1.2 million $\mathrm{m}^{3} \cdot$ year $^{-1}$ at a declining rate of about $0.4 \%$. Our estimates are well within wood production estimated the World Bank et al. [37] and DAI [25] whose annual wood production (including illegal production) was reported at 1.5 - 4.3 million $\mathrm{m}^{3}$ from 1995 to 1997.

\subsection{Carbon Stock Changes under CVL, RIL, and RIL+}

Affected by logging practices, carbon stocks in 3.4 million ha of concession forests decrease to $125.6 \mathrm{Tg} \mathrm{C}$ at the year $55^{\text {th }}$ (the ending year of the modeling timeframe, $\mathrm{t}=55)$ from $315.26 \mathrm{TgC}$ at the start of the management $(\mathrm{t}$ $=0$ ), representing an annual degradation (emissions) of $3.4 \mathrm{TgC}$ or $12.7 \mathrm{TgCO}_{2}\left(1 \mathrm{TgC}=44 / 12 \mathrm{TgCO}_{2}=3.67\right.$ million tonnes $\mathrm{CO}_{2}$ ) or $1.1 \%$ annually. Respectively under the RIL and RIL+, carbon stocks also decrease to 186.2 and 216.7 $\mathrm{TgC}$ at $\mathrm{t}=55$ from 315.2 $\mathrm{TgC}$ at $\mathrm{t}=0$, representing annual emissions from forest degradation of $7.6 \mathrm{TgCO}_{2}(0.7 \%)$ and $6.6 \mathrm{TgCO}_{2}(0.6 \%)$ over a 55 -year modeling timeframe (Figure 3).

Illegal logging also strongly affects carbon stocks in the forests. If half of the rate of illegal logging used in our study is halted, annual carbon loss (degradation) is 8.8 $\mathrm{TgCO}_{2}, 4.9 \mathrm{TgCO}_{2}$, and $2.7 \mathrm{TgCO}_{2}$ under CVL, RIL, and RIL+ scenarios, respectively. If illegal logging is completely eliminated, managing concession forests under the CVL, RIL, and RIL+ scenario results in annual carbon loss (degradation) of 6.2, 2.7, and $0.3 \mathrm{TgCO}_{2}$, respectively over the 55-year cutting cycle (Figure 4).

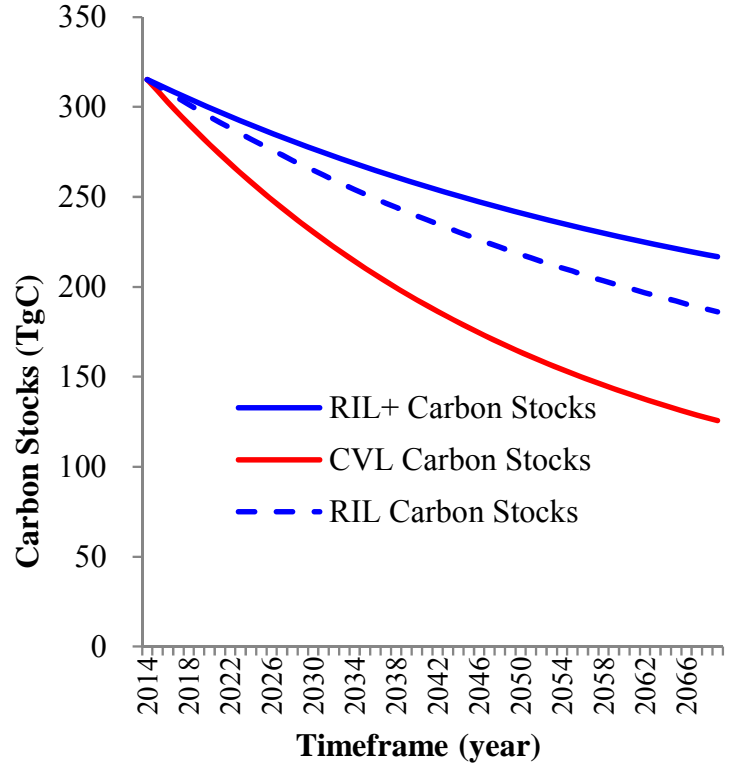

Figure 3. Forest carbon stocks of 25-year cutting cycle under three logging practices (2014-2069).

As previous study on reduced emissions from forest degradation through managing concession forests was very limited, it is difficult to compare our carbon emission reductions with that of previous studies. However, Asner et al. [45,46] found that at least $20 \%$ of tropical forests were under various forms of selectively logging, and forest degradation in Amazon doubled during the 2000s. Conventional logging also caused rapid deforestation in Amazon, where selectively logged forests were cleared in four years after logging [8] suggesting that large amount of timber volume (carbon) was harvested and degraded during and after logging. 


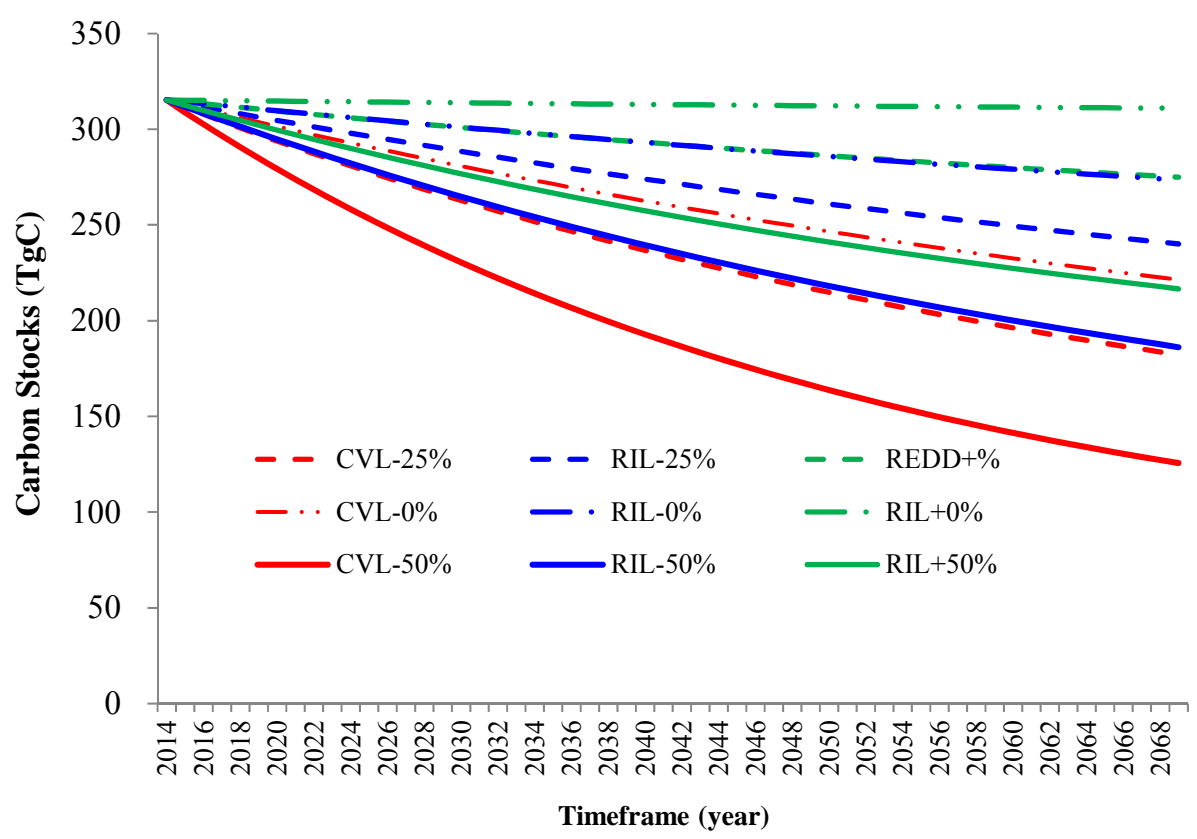

Figure 4. Carbon stock changes affected by illegal logging under CVL, RIL, and RIL+. Note: CVL-50\%, CVL—25\%, and CVL- $0 \%$ are carbon stocks under $50 \%, 20 \%$, and $0 \%$ rates of illegal logging.

\subsection{Sensitivity Analysis of Illegal Logging and Cutting Cycles}

To analyze the impact of illegal logging and cutting cycle on timber supply and carbon stocks, and thus carbon emissions from managing 3.4 million ha of concession forests in Cambodia, three more cutting cycles, namely 35,45 , and 55 years were tested under the CVL, RIL, and RIL+ scenarios with three rates of illegal logging, namely the $50 \%$ rate, $25 \%$ rate, and zero. The testing results for a $50 \%$ rate of illegal indicate that the annual end-use wood products from managing the 3.4 million ha of concession forests are 1.8 (declining 1.1\% annually), $1.4(0.8 \%)$, and 1.2 million $\mathrm{m}^{3}(0.6 \%)$ under 35,45 , and 55 years cutting cycles, respectively for a 55-year modeling timeframe. If the rate of illegal logging is reduced by $50 \%(\mathrm{r}=0.5 / 2)$, end-wood products were estimated at $1.3(0.6 \%), 1.0(0.4 \%)$, and $0.8(0.2 \%)$ million $\mathrm{m}^{3} \cdot$ year $^{-1}$, and if the rate of illegal logging is completely reduced $(\mathrm{r}$ $=0)$, end-use wood products are estimated at $1.0(0.3 \%)$, $0.8(0.2), 0.6(0.1 \%)$ million $\mathrm{m}^{3} \cdot$ year $^{-1}$, respectively (Table 2). If illegal logging is completely eliminated, a 55-year cutting cycle would be most appropriate and it could ensure the sustainable supply of end-use wood product of 0.9 million $\mathrm{m}^{3}$ under the RIL or RIL+ practice. Given the nature of illegal logging and governance problems in developing countries, it is unlikely that illegal logging can be completely eliminated.

Cutting cycle and illegal logging rates also affect forest carbon stocks (Table 3). Annual carbon emissions over a 55-year period under the CVL, RIL and RIL+ of a 35-year cutting cycle with 50\% rate of illegal logging were estimated at $9.52(0.82 \%), 5.60(0.48 \%)$, and 3.31 $(0.29 \%) \mathrm{TgCO}_{2}$, respectively. With $25 \%$ rate, carbon emissions were $5.84(0.50 \%), 2.44(0.21 \%)$, and -0.08 $\left(-0.01 \%\right.$, “-" refers to carbon sinks) $\mathrm{TgCO}_{2}$, and 3.50, 0.60 , and $-2.06 \mathrm{TgCO}_{2}$ without illegal logging, respectively under CVL, RIL, and RIL+ (Table 3). Carbon sequestration was achieved under the RIL and RIL+ of 45-year cutting cycle $\left(-0.74\right.$ and $-3.49 \mathrm{TgCO}_{2}$ year ${ }^{-1}$, respectively) without illegal logging. Under a 55-year cutting cycle, carbon sequestration of $-0.43-4.46$ $\mathrm{TgCO}_{2}$ year $^{-1}$ was achieved by switching from CVL to RIL and by reducing the rate of illegal logging (Table 3). From a carbon perspective, the longer the rotation is the more carbon sinks can be achieved.

Taking into account the need for investment return, a shorter cutting cycle is preferred by forest owners. Depending on incentives from the REDD+ scheme and timber prices, forest managers or owners are likely to choose either a 35-year or 45-year cutting cycle through the adoption of RIL or RIL+. If carbon price is not attractive enough and timber price is high, forest owners will try to maximize their revenues under a shorter but appropriate cycle provided that carbon emissions can be achieved against the baseline scenario. RIL or RIL+ is likely to become their choice if carbon incentives are available. At a country level, countries with instable political situation are likely to adopt the short cutting cycles for immediate financial gains in the expense of forest resources and carbon stocks. Such practices were actually behind the rapid forest degradation and deforestation 
Table 2. Average annual end-use wood product under four cutting cycles and three rates of illegal logging for 55-year time span.

\begin{tabular}{ccccccc}
\hline \multirow{2}{*}{ Cutting Cycle } & \multicolumn{2}{c}{ Illegal logging rate: $50 \%$} & \multicolumn{2}{c}{ Illegal logging rate: $25 \%$} & \multicolumn{3}{c}{ Illegal logging rate: $0 \%$} \\
\cline { 2 - 7 } & $\left(\right.$ million $\left.\mathrm{m}^{3}\right)$ & Decline $(\%)$ & $\left(\right.$ million $\left.\mathrm{m}^{3}\right)$ & Decline $(\%)$ & $\left(\right.$ million $\left.\mathrm{m}^{3}\right)$ & Decline $(\%)$ \\
\hline 25-year cycle & 2.28 & -1.51 & 1.67 & -0.97 & 1.32 & -0.65 \\
35-year cycle & 1.77 & -1.05 & 1.27 & -0.60 & 0.98 & -0.34 \\
45-year cycle & 1.44 & -0.76 & 1.02 & -0.37 & -0.78 & -0.17 \\
55 -year cycle & 1.22 & -0.55 & 0.85 & -0.22 & 0.65 & -0.05 \\
\hline
\end{tabular}

Note: Values in this table are the average for 25-year modeling timeframe.

Table 3. Annual carbon emissions or sinks under four cutting cycles and three rates of illegal logging (modeling timeframe: 55 years).

\begin{tabular}{|c|c|c|c|c|c|c|c|c|c|}
\hline & \multicolumn{9}{|c|}{ Rates of illegal logging } \\
\hline & \multicolumn{3}{|c|}{$50 \%$} & \multicolumn{3}{|c|}{$25 \%$} & \multicolumn{3}{|c|}{$0 \%$} \\
\hline \multicolumn{10}{|c|}{ 25-year cutting cycle } \\
\hline$\left(\mathrm{TgCO}_{2}\right)$ & 12.65 & 8.61 & 6.58 & 8.88 & 5.02 & 2.69 & 6.26 & 2.79 & 0.29 \\
\hline$\%$ & $1.09 \%$ & $0.74 \%$ & $0.57 \%$ & $0.77 \%$ & $0.43 \%$ & $0.23 \%$ & $0.54 \%$ & $0.24 \%$ & $0.02 \%$ \\
\hline \multicolumn{10}{|c|}{ 35-year cutting cycle } \\
\hline$\left(\mathrm{TgCO}_{2}\right)$ & 9.52 & 5.60 & 3.31 & 5.84 & 2.44 & -0.08 & 3.50 & 0.60 & -2.06 \\
\hline$\%$ & $0.82 \%$ & $0.48 \%$ & $0.29 \%$ & $0.50 \%$ & $0.21 \%$ & $-0.01 \%$ & $0.30 \%$ & $0.05 \%$ & $-0.18 \%$ \\
\hline$\left(\mathrm{TgCO}_{2}\right)$ & 7.20 & 3.57 & 1.13 & 3.78 & 0.81 & -1.83 & 1.73 & -0.74 & -3.49 \\
\hline$\%$ & $0.62 \%$ & $0.31 \%$ & $0.10 \%$ & $0.33 \%$ & $0.07 \%$ & $-0.16 \%$ & $0.15 \%$ & $-0.06 \%$ & $-0.30 \%$ \\
\hline \multicolumn{10}{|c|}{ 55-year cutting cycle } \\
\hline$(\mathrm{TgCO} 2)$ & 5.44 & 2.12 & -0.43 & 2.31 & -0.30 & -3.03 & 0.49 & -1.64 & -4.46 \\
\hline$\%$ & $0.47 \%$ & $0.18 \%$ & $-0.04 \%$ & $0.20 \%$ & $-0.03 \%$ & $-0.26 \%$ & $0.04 \%$ & $-0.14 \%$ & $-0.39 \%$ \\
\hline
\end{tabular}

Note: $1 \mathrm{TgC}=3.67 \mathrm{TgCO}_{2}=3.67$ million tonnes $\mathrm{CO}_{2}$ and “- or minus" refers to carbon sinks.

in the tropics in the last several decades [47]. It is therefore important that incentives under the REDD + scheme weight the benefits of managing the forests and the right incentives for developing countries while make sure that bad practice is not accepted.

Based on past experience with illegal logging and government capability to completely reduce illegal logging, a 45 -year cutting cycle with $25 \%$ rate of illegal logging is more realistic, and it was assumed here to be adopted for managing forests under the REDD+ scheme. With this assumption, we can estimate the emissions in the absence of the REDD+ activities and emissions when REDD+ activities are implemented. The former is usually known as reference emission level (REL) while the later is known as project emission level (PEL).

\subsection{Carbon Emission Reductions and Carbon Credits}

By taking 25-year (currently practiced cycle) cycle as baseline cycle, against which a 45 -year cutting cycle is compared, REL, PEL and carbon credits can be estimated. Based on equations (12) through (15), REL was estimated at $12.4 \mathrm{TgCO}_{2}$ year ${ }^{-1}$ over the 55 -year modeling period. Over the same period, PELs under RIL and RIL+ were estimated at 3.5 and $1.1 \mathrm{TgCO}_{2}$ year $^{-1}$, respectively (Figure 5). Therefore, the annual emission reductions from forest degradation were 8.9 or $11.3 \mathrm{TgCO}_{2}$ year $^{-1}$, respectively if CVL was replaced by RIL or RIL+. After subtracting $30 \%$ from, CC under the RIL or RIL+ was estimated at about $6.2 \mathrm{TgCO}_{2}$ year ${ }^{-}$or $7.9 \mathrm{TgCO}_{2}$ year $^{-}$ 


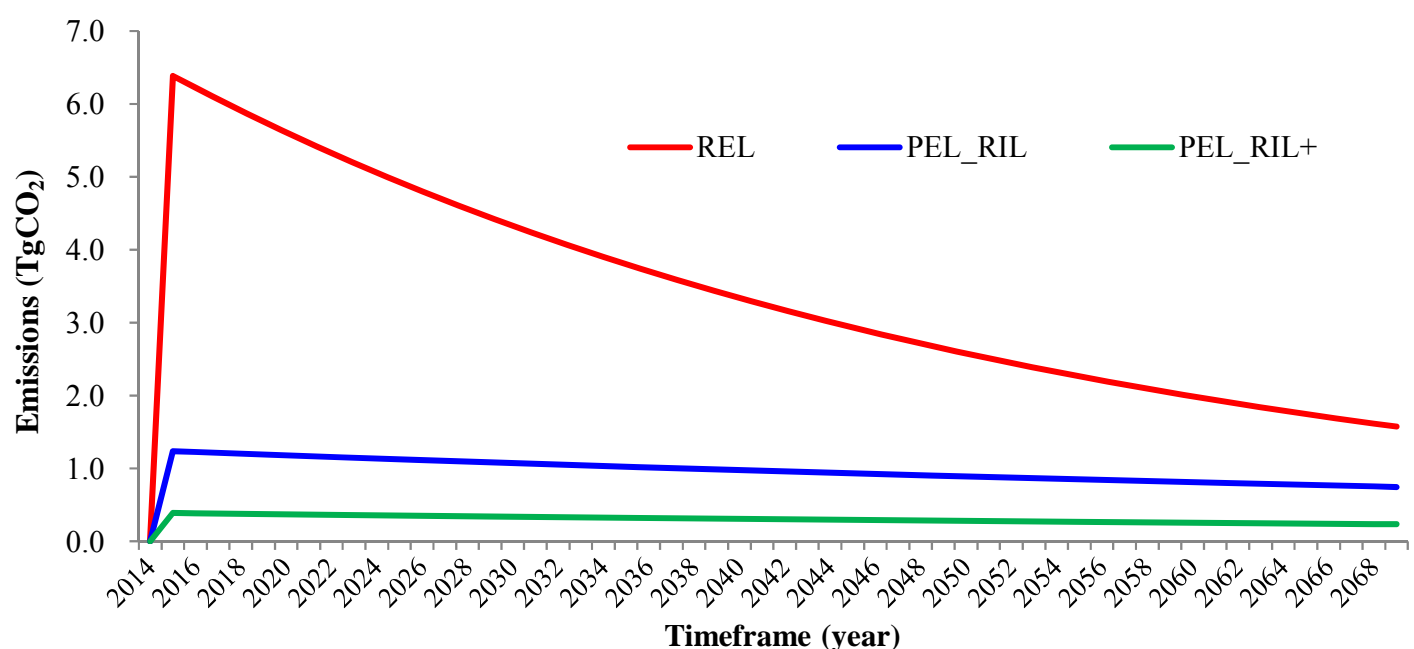

Figure 5. Reference emission level (red) and project emission level under RIL (blue) and under RIL+ (green). Note: PEL_RIL and PEL_RIL+ are project emission levels under the RIL and RIL+ scenarios, respectively.

under RIL or RIL+, respectively. If carbon is priced at $\$ 5$ (average carbon price at the voluntary carbon market was $\$ 5.90$ per $\mathrm{MgCO}_{2}$ in 2012 [48], total annual carbonbased revenues from managing 3.4 million ha of concession forests were estimated at $\$ 31.0$ - 39.5 million annually for 55 years by adopting RIL or RIL+ practice. In addition to these carbon revenues, revenues from timber royalties and other benefits from long-term management of production forests can also be obtained. The carbon revenues alone are more than four times higher than the timber revenues from logging in Cambodia reported in 1995 [40].

\subsection{Project Activities and Costs}

It is obvious that achieving high PEL requires project activities that reduce logging damages, logging residues (wood wastes in the forests) and wood wastes at the wood processing factory. The RIL activities for reducing logging damages include logging training and mapping, well-defined logging plan, directional felling, tree felling and skidding by trained crews, pre- and post-logging social and environmental impact assessments, post-logging assessments. Activities for reducing wood wastes include training on directional felling, tree felling, log trimming and exporting, and introducing wood processing technology at the processing mills. In addition, government's commitment to enforcing the laws and transparency in logging practice and revenue sharing to relevant stakeholders such as forest-dependent community are required for the successful implementation of the sustainable forest management projects.

Logging costs had been generally thought to be expensive under the RIL or RIL+ options but based on various studies in the tropics, Sasaki et al. [18] argued costs are not expensive as previously thought because revenues under CVL continuously declines as future commercial timber supply is decreasing. However, costeffective analysis is beyond the scope of this paper.

\section{Conclusions}

Improved forest management through adoption of RIL+ could result in significant reductions of carbon emissions due to selective logging. Our study suggests that carbon credits generated from switching from destructive logging to sound logging practice (i.e. RIL or RIL+) are huge and would be attractive to project developers if there are continued financial incentives and/or carbon markets for carbon credits from sustainable management of forests. The inclusion of the SFM of the REDD+ scheme in the new mitigation mechanisms for postKyoto project activities will ensure such incentives and carbon markets.

Our results also suggested that a 25 -year cutting cycle currently being practiced in Cambodia is too short to maintain the flow of wood production. A 45-year cutting cycle under the RIL or RIL+ could maintain the longterm supply of wood product while still contributing to carbon emission reductions from selectively logged forests. Achieving sustainable forest management under the REDD + mechanism will require the adoption of sound logging practices that will reduce damage to forest residual stands and the soils that sustain these stands, and that will therefore reduce disturbances to upstream resources (e.g., forests that protect catchment ecosystem services) while maintaining a flow of wood products. Therefore, RIL or RIL+ should be adopted for improving forest management in the tropics under the REDD+ scheme. Without carbon-based incentives such as carbon incentives under the REDD+ scheme, RIL+ would not be adopted and therefore emissions from tropical forests can 
not be reduced putting global efforts to mitigating climate change and achieving sustainable development in developing countries at risk.

For adopting RIL+, pre-cautionary measures should be taken to prevent the killing of commercially less important but biologically important tree species. This practice of tree girdling should be carefully practiced by welltrained professionals who have knowledge about tree species and their interactions with other organisms in the forests.

\section{Acknowledgements}

This study was partially supported by a Grant-in-Aid for Scientific Research (No. 18402003) from the Ministry of Education, Culture, Sports, Science and Technology of Japan.

\section{REFERENCES}

[1] P. Friedlingstein, R. A. Houghton, G. Marland, J. Hackler, T. A. Boden, T. J. Conway, J. G. Canadell, M. R. Raupach, P. Ciais and C. Le Quéré, "Update on $\mathrm{CO}_{2}$ Emissions," Nature Geoscience, Vol. 3, No. 12, 2010, pp. 811-812. http://dx.doi.org/10.1038/ngeo1022

[2] Y. Pan, R. A. Birdsey, J. Fang, R. Houghton, P. E. Kauppi, W. A. Kurz, O. L. Phillips, A. Shvidenko, S. L. Lewis, J. G. Canadell, P. Ciais, R. B. Jackson, S. Pacala, A. D. McGuire, S. Piao, A. Rautiainen, S. Sitch and D. Hayes, "A Large and Persistent Carbon Sink in the World's Forests," Science, Vol. 333, No. 6045, 2011, pp. 988-993. http://dx.doi.org/10.1126/science.1201609

[3] G. Kindermann, M. Obersteiner, B. Sohngen, J. Sathaye, K. Andrasko, E. Rametsteiner, B. Schlamadinger, S. Wunder and R. Beach, "Global Cost Estimates of Reducing Carbon Emissions through Avoided Deforestation," Proceedings of the National Academy of Sciences of the United States of America, Vol. 105, No. 30, 2008, pp. 10302-10307. http://dx.doi.org/10.1073/pnas.0710616105

[4] N. Sasaki and A. Yoshimoto, "Benefits of Tropical Forest Management under the New Climate Change Agreement-A Case Study in Cambodia," Environmental Science \& Policy, Vol. 13, No. 5, 2010, pp. 384-392.

http://dx.doi.org/10.1016/j.envsci.2010.04.007

[5] F. Toni, "Decentralization and REDD+ in Brazil," Forests, Vol. 2, No. 1, 2011, pp. 66-85.

[6] N. Sasaki, K. Chheng and S. Ty, "Managing Production Forests for Timber Production and Carbon Emission Reductions under the REDD+ Scheme," Environmental Science \& Policy, Vol. 23, 2012, pp. 35-44. http://dx.doi.org/10.1016/j.envsci.2012.06.009

[7] F. E. Putz, P. A. Zuidema, M. A. Pinard, R. G. A. Boot, J. A. Sayer, D. Sheil, P. Sist and J. K. Vanclay, "Improved Tropical Forest Management for Carbon Retention," PLOS Biology, Vol. 6, No. 7, 2008, Article ID: e166. http://dx.doi.org/10.1371/journal.pbio.0060166

[8] G. P. Asner, E. N. Broadbent, P. J. Oliveira, M. Keller, D. E. Knapp and J. N. Silva, "Condition and Fate of Logged
Forests in the Brazilian Amazon," Proceedings of the National Academy of Sciences of the United States of America, Vol. 103, No. 34, 2006, pp. 12947-12950. http://dx.doi.org/10.1073/pnas.0604093103

[9] D. W. Pearce, E. F. Putz and J. K. Vanclay, "Sustainable Forestry in the Tropics: Panacea or Folly?" Forest Ecology and Management, Vol. 172 No. 2-3, 2003, pp. 229247. http://dx.doi.org/10.1016/S0378-1127(01)00798-8

[10] N. Sasaki and F. E. Putz, "Critical Need for New Definitions of Forest and Forest Degradation in Global Climate Change Agreements," Conservation Letters, Vol. 2, No. 5, 2009, pp. 226-232. http://dx.doi.org/10.1111/j.1755-263X.2009.00067.x

[11] S. D. Miller, M. L. Goulden, L. R. Hutyra, M. Keller, S. R. Saleska, S. C. Wofsy, A. M. Figueira, H. R. Da Rocha and P. B. De Camargo, "Reduced Impact Logging Minimally Alters Tropical Rainforest Carbon and Energy Exchange," Proceedings of the National Academy of Sciences of the United States of America, Vol. 108, No. 48, 2011, pp. 19431-19435.

http://dx.doi.org/10.1073/pnas.1105068108

[12] N. Kim Phat, W. Knorr and S. Kim, "Appropriate Measures for Conservation of Terrestrial Carbon StocksAnalysis of Trends of Forest Management in Southeast Asia," Forest Ecology and Management, Vol. 191, No. 1-3, 2004, pp. 283-299. http://dx.doi.org/10.1016/j.foreco.2003.12.019

[13] N. Sasaki, "Carbon Emissions Due to Land-Use Change and Logging in Cambodia-A Modeling Approach," Journal of Forest Research, Vol. 11, No. 6, 2006, pp. 397-403. http://dx.doi.org/10.1007/s10310-006-0228-5

[14] P. Sist, D. Sheil, K. Kartawinata and H. Priyadi, "Reduced-Impact Logging in Indonesian Borneo: Some Results Confirming the Need for New Silvicultural Prescriptions," Forest Ecology and Management, Vol. 179, No. $1-3,2003$, pp. 415-427. http://dx.doi.org/10.1016/S0378-1127(02)00533-9

[15] S. Ty, N. Sasaki, A. H. Ahmad and A. Z. Zainal, "REDD Development in Cambodia-Potential Carbon Emission Reductions in a REDD Project," FORMATH, Vol. 10, 2011, pp. 1-23.

[16] FAO, “Global Forest Resources Assessment 2010," FAO Forestry Paper, Vol. 163, FAO, Rome, 2010.

[17] FA (Forestry Administration), "Forest Cover Statistics in Cambodia 2002-2010,” FA, Phnom Penh, 2011.

[18] N. Sasaki, G. P. Asner, W. Knorr, P. B. Durst, H. Priyadi and F. E. Putz, "Approaches to Classifying and Restoring Degraded Tropical Forests for the Anticipated REDD+ Climate Change Mitigation Mechanism," iForest-Biogeosciences and Forestry, Vol. 4, 2011, pp. 1-6.

[19] T. P. Holmes, G. M. Blate, J. C. Zweede, R. Pereira, P. Barreto, F. Boltz and R. Bauch, "Financial and Ecological Indicators of Reduced Impact Logging Performance in the Eastern Amazon," Forest Ecology and Management, Vol. 163, No. 1-3, 2002, pp. 93-110. http://dx.doi.org/10.1016/S0378-1127(01)00530-8

[20] M. Peña-Claros, T. S. Fredericksen, A. Alarcón, G. M. Blate, U. Choque, C. Leaño, J. C. Licona, B. Mostacedo, 
W. Pariona, Z. Villegas and F. E. Putz, "Beyond Reduced-Impact Logging: Silvicultural Treatments to Increase Growth Rates of Tropical Trees," Forest Ecology and Management, Vol. 256, No. 7, 2008, pp. 1458-1467. http://dx.doi.org/10.1016/j.foreco.2007.11.013

[21] Z. Villegas, M. Peña-Claros, B. Mostacedo, A. Alarcón, J. C. Licona, C. Leaño, W. Pariona and U. Choque, "Silvicultural Treatments Enhance Growth Rates of Future Crop Trees in a Tropical Dry Forest," Forest Ecology and Management, Vol. 258, No. 6, 2009, pp. 971-977. http://dx.doi.org/10.1016/j.foreco.2008.10.031

[22] S. Brown, "Estimating Biomass and Biomass Change of Tropical Forest: A primer. FAO Forestry Paper 134," Food and Agriculture Organization of the United Nations (FAO), Cambridge, Rome, 1997.

[23] N. Kim Phat, S. Ouk, Y. Uozumi and T. Ueki, "Stand dynamics of Dipterocarp trees in Cambodia's Evergreen Forest and Management Implications-A Case Study in Sandan District, Kampong Thom," Journal of Forest Planning, Vol. 6, No. 1, 2000, pp. 13-23.

[24] MAFF, "Sub-Decree No. 050 on Tree Species Classification and Diameter Limit for Harvesting," MAFF, Phnom Penh (in Khmer), 1986.

[25] DAI (Development Alternatives, Inc.), "Findings and Recommendations of the Log Monitoring and Logging Control Project," Reported Submitted to the Royal Government of Cambodia, Department of Forestry and Wildlife, Phnom Penh, Cambodia, 1998.

[26] WRI (World Resource Institute), "World Resources 2002-2004: Decisions for the Earth: Balance, Voice, and Power," World Resources Institute, Washington DC, 2003.

[27] C. Nellemann, L. Miles, B. P. Kaltenborn, M. Viture and H. Ahlenius, "The Last Stand of the Orangutan-State of Emergency: Illegal Logging, Fire and Palm Oil in Indonesia's National Parks," United Nations Environment Program and United Nations Economic, Social and Cultural Office, Arendal, 2007.

[28] C. P. Hansen and T. Treue, "Assessing Illegal Logging in Ghana," International Forestry Review, Vol. 10, No. 4, 2008, pp. 573-590. http://dx.doi.org/10.1505/ifor.10.4.573

[29] S. Lawson and L. Macfaul, "Illegal Logging and Related Trade Indicators of the Global Response," Chatham House, London, 2010.

[30] N. Kim Phat, S. Kim, S. Ouk, Y. Uozumi and T. Ueki, "Management of Mixed Forest in Cambodia-A Case Study in Sandan District, Kampong Thom," Bulletin of Faculty of Agriculture, Shinshu University, Vol. 38, No. 1-2, 2002, pp. 45-54.

[31] N. Kim Phat, S. Ouk, Y. Uozumi, T. Ueki and S. Kim, "Management of Mixed Deciduous Forest in Central Cambodia-A Case Study in Sandan District," Bulletin of Shinshu University Forest Research, Vol. 2, No. 38, 2002, pp. 290-309.

[32] D. Kao and S. Iida, "Structural Characteristics of Logged Evergreen Forests in Preah Vihear, Cambodia, 3 Years after logging," Forest Ecology and Management, Vol.
225, No. 1-3, 2006, pp. 62-73. http://dx.doi.org/10.1016/j.foreco.2005.12.056

[33] K. Chheng, N. Sasaki and N. Mizoue, "Impacts of Reduced Impact Logging on Stand Structures in Mixed Forests in Three Northeastern Provinces in Cambodia," 2nd International Conference on FORCOM Follow-Up and New Challenge for Coming Generations, Mie, 25-30 September 2011, $23 \mathrm{p}$.

[34] N. Top, N. Mizoue and S. Kai, "Estimating Forest Biomass Increment Based on Permanent Sample Plots in Relation to Woodfuel Consumption: A Case Study in Kampong Thom Province, Cambodia," Journal of Forest Research, Vol. 9, No. 2, 2004, pp. 117-123. http://dx.doi.org/10.1007/s10310-003-0064-9

[35] S. L. Lewis, G. Lopez-Gonzalez, B. Sonke, K. AffumBaffoe, T. R. Baker, L. O. Ojo, et al., "Increasing Carbon Storage in intact African Tropical Forests," Nature, Vol. 457, No. 7232, 2009, pp. 1003-1006. http://dx.doi.org/10.1038/nature07771

[36] O. L. Phillips, Y. Malhi, N. Higuchi, W. F. Laurance, P. V. Nunez, R. M. Vasquez, S. G. Laurance, L. V. Ferreira, M. Stern, S. Brown and J. Grace, "Changes in the Carbon Balance of Tropical Forests: Evidence from Long-Term Plots," Science, Vol. 282, No. 5388, 1998, pp. 439-442. http://dx.doi.org/10.1126/science.282.5388.439

[37] World Bank, United Nations Development Program (UNDP) and FAO, "Cambodian Forest Policy Assessment," World Bank, Phnom Penh, 1996.

[38] Center for Forestry Planning and Statistics and Ministry of Forestry, "Indonesia Forestry Outlook," Asia-Pacific forestry sector study II, Working Paper No. APFSOS II/WP/2009/13, FAO, Bangkok, 2009.

[39] H. Priyadi, P. Gunarso, P. Sist and H. Dwiprabowo, "Reduced-Impact Logging (RIL) Research and Development in Malinau Research Forest, East Kalimantan: A Challenge of RIL Adoption," Paper presented in the Regional Workshop, RIL Implementation in Indonesia with Reference to Asia-Pacific Region: Review and Experiences, Bogor, 15-16 February 2006, 18 p.

[40] S. Kim, N. Kim Phat, M. Koike and H. Hayashi, "Estimating Actual and Potential Government Revenues from timber Harvesting in Cambodia," Forest Policy and Economics, Vol. 8, No. 6, 2006, pp. 625-635. http://dx.doi.org/10.1016/j.forpol.2004.12.001

[41] FAO (Food and Agriculture Organization of the United Nations), "Financial and Economic Assessment of Timber Harvesting Operations in Sarawak, Malaysia," Forest Harvesting Case-Studies 17, FAO, Rome, 2001.

[42] P. Sist and A. Saridan, "Description of the Primary Lowland Forest of Berau," In: J. G. Bertault and K. Kadir, Eds., Silvicultural Research in a Lowland Mixed Dipterocarp Forest of East Kalimantan: The Contribution of STREK Project, CIRADFORDA-P.T. INHUTANII, Indonesia, 1998, pp. 51-94.

[43] B. C. Murray, B. A. Mccarl and H. C. Lee, "Estimating Leakage from Forest Carbon Sequestration Programs," Working Paper, 2-6 May 2002, RTI International, 2002, pp. 1-22.

[44] D. C. Nepstad, A. Veri'Ssimo, A. Alencar, C. Nobre, E. 
Lima, P. Lefebvre, P. Schlesinger, C. Potter, P. Moutinho, E. Mendoza, M. Cochrane and V. Brooks, "Large-scale Impoverishment of Amazon Forests by Logging and Fire," Nature, Vol. 398, No. 6727, 1999, pp. 505-508. http://dx.doi.org/10.1038/19066

[45] P. G. Asner, K. T. Rudel, T. M. Aide, R. Defries and R. Emerson, "A Contemporary Assessment of Change in Humid Tropical Forests," Conservation Biology, Vol. 23, No, 6, 2009, pp. 1386-1395.

http://dx.doi.org/10.1111/j.1523-1739.2009.01333.x

[46] G. P. Asner, G. V. N. Powell, J. Mascaro, D. E. Knapp, J. K. Clark, J. Jacobson, T. Kennedy-Bowdoin, A. Balaji, G. Paez-Acosta, E. Victoria, L. Secada, M. Valqui and R. F. Hughes, "High-Resolution Carbon Stocks and Emissions in the Amazon," Proceedings of the National Academy of Sciences of the United States of America, Vol. 107, No. 38, 2010, pp. 16738-16742. http://dx.doi.org/10.1073/pnas.1004875107

[47] A. Casson and K. Obidzinski, "From New Order to Regional Autonomy: Shifting Dynamics of 'illegal' Logging in Kalimantan, Indonesia," World Development, Vol. 30, No. 12, 2002, pp. 2133-2151. http://dx.doi.org/10.1016/S0305-750X(02)00125-0

[48] M. Peters-Stanley and D. Yin, "Maneuvering the Mosaic State of the Voluntary Carbon Markets 2013," A Report by Forest Trends' Ecosystem Marketplace \& Bloomberg New Energy Finance, Washington, D.C., 2013, pp. 126. 